\title{
PRELIMINARY NOTE ON THE REPRODUCTION OF RHODYMENIA
}

PALMATA, Ag.- In spite of the large amount of material of Rhodymenia palmata, Ag., available on the shores of the Northern Hemisphere, no account of sexual reproduction in this species has been published. Indeed, as recently as I 9 19, Dr. Church 1 cited this alga as an example of a member of the Rhodophyceae in which the sexual phase might be regarded as omitted from the life-cycle.

Asexual reproduction. Asexual reproduction is known to take place by means of tetraspores embedded in the outer small-celled tissue of the thallus, 'scattered or in cloudy patches '.2

These tetrasporic thalli were found in large numbers, both in the spring and

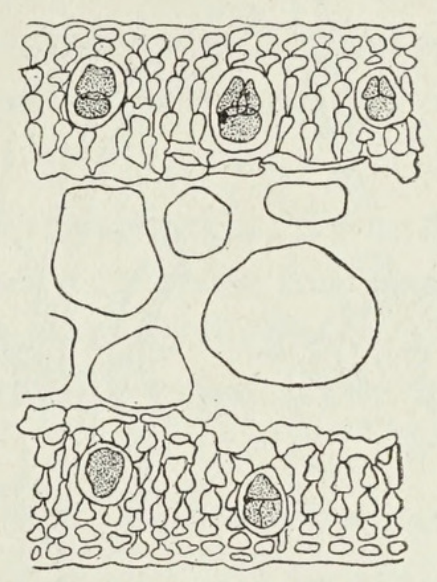

FIG. I. Transverse section of a tetrasporic thallus of Rhodymenia palmata, showing the scattered groups of tetraspores embedded in the tissue forming the outer cortex of the thallus. Camera lucida outline. $\times 250$.

autumn (April to September), at Shanklin, Isle of Wight. The tetrasporangia were either-

I. Scattered singly in the cortical tissue of the thallus (Fig. I), giving the frond a mottled appearance in surface view; or,

2. Aggregated in sori, which may be marginal or may occupy the centre of the frond.

Sexual reproduction. The procarpial fronds were first found in April 1922, in some material gathered at random from the rocks at Shanklin.

These fronds are similar in form and colour to the vegetative or tetrasporic ones, but on examination the upper part of the frond is seen to be thinner and paler in texture than the rest, and is covered with minute, dark, ill-defined spots which sections show to be groups of procarps. These are developed on both surfaces of the fronds and are not scattered, but are aggregated into small groups situated near each other and arranged in regular acropetal succession.

The procarps are developed from among the smaller cells of the outer thallus tissue ; when first differentiated each procarp consists of one or two cells (Fig. 2, A), but later these divide, giving a chain of three or four (Fig. 2, в). The upper cell

1 Church, A. H. : Historical Review of the Florideae. Journ. Bot., lvii, 1919, p. 329.

2 Harvey, W. H. : Phycologia Britannica, 187 r, vol. iii. 
develops a very long hyaline outgrowth - the trichogyne-which first arises as a small blunt protuberance of protoplasm from the carpogonium, covered by the extended gelatinous wall of the thallus (Fig. 2, A). When mature, the trichogyne may be as much as $0.3 \mathrm{I} \mathrm{mm}$. in length; the apex is somewhat swollen, the contents staining deeply with Heidenhain's iron-alum-haematoxylin, while the base is constricted at the point of attachment to the carpogonium (Fig. 2, A and B).

The trichogyne nucleus; which appears to be characteristic of those Rhodophyceae which include an asexual phase in their life-cycle, is an absolutely constant feature in $R$. palmata. It is a well-marked, spherical body, situated approximately half-way

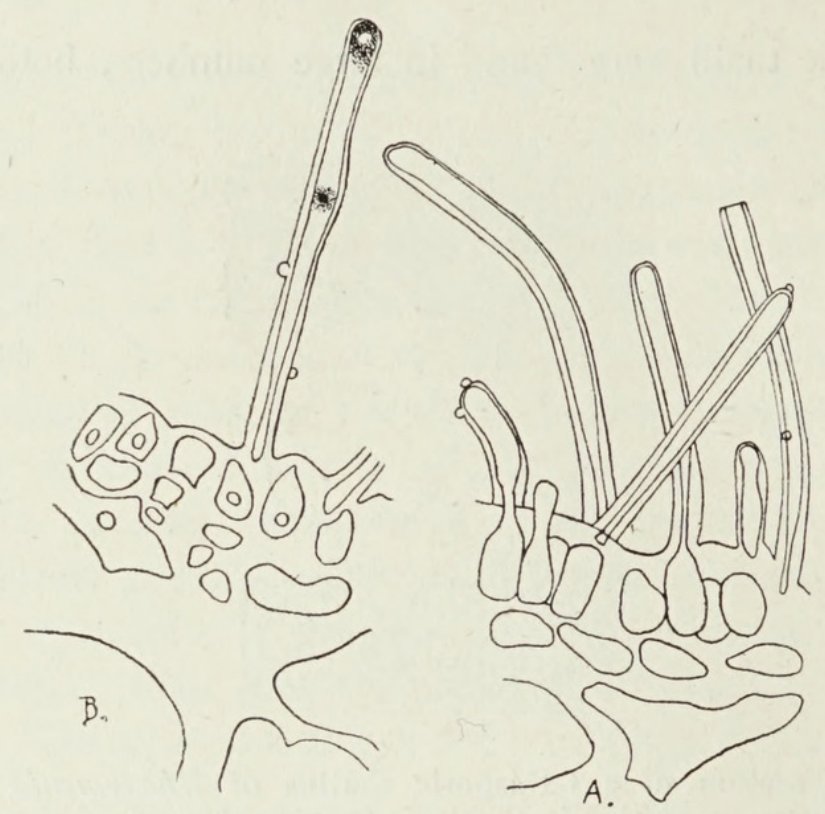

FIG. 2. Outline drawings of transverse sections through procarpial thalli. A. Section through a group of young procarps, showing the trichogyne in various stages of development. B. Section through mature procarps, showing the chains of cells, and an elongated trichogyne with its nucleus. Both drawn with camera lucida. $\times 75^{\circ}$.

down the trichogyne (Fig. 2, в), and it remains visible until the latter shrivels up and disappears.

The antheridial fronds have not yet been recognized, but spherical bodies closely resembling spermatia have been found seated in various positions on the majority of trichogynes. More than one of these bodies is usually found on a single trichogyne (Fig. 2, B).

Further investigation is taking place into the differentiation of auxiliary cells, the fusions following fertilization, and the production of carpospores.

\section{Summary.}

I. The discovery of the female fronds of Rhodymenia palmata, Ag., is recorded, the procarps being developed in groups in acropetal succession.

2. Each procarp bears a long trichogyne, with a distinct trichogyne nucleus. Bodies resembling spermatia have been seen seated on the trichogynes.

3. Further work on the development of the carpospores is expected to confirm the systematic position of Rhodymenia palmata as a member of the Rhodymeniales.

Westfield College, London, V. M. GRUBB. 


\section{$2 \mathrm{BHL}$ Biodiversity Heritage Library}

Grubb, Violet M. 1923. "Preliminary note on the reproduction of Rhodymenia palmata, Ag." Annals of botany 37, 151-152.

https://doi.org/10.1093/oxfordjournals.aob.a089832.

View This Item Online: https://www.biodiversitylibrary.org/item/270686

DOI: https://doi.org/10.1093/oxfordjournals.aob.a089832

Permalink: https://www.biodiversitylibrary.org/partpdf/319075

\section{Holding Institution}

New York Botanical Garden, LuEsther T. Mertz Library

\section{Sponsored by}

BHL-SIL-FEDLINK

\section{Copyright \& Reuse}

Copyright Status: Public domain. The BHL considers that this work is no longer under copyright protection.

This document was created from content at the Biodiversity Heritage Library, the world's largest open access digital library for biodiversity literature and archives. Visit BHL at https://www.biodiversitylibrary.org. 